\title{
Absolute Configurations of Mytiloxanthin and 9-E-Mytiloxanthin
}

\author{
Takashi MAOKA*1,*2 and Yasuhiro FUJIWARA*1 \\ *1 Kyoto Pharmaceutical University \\ (Misasagi, Yamashina-ku, Kyoto-shi, ₹607) \\ $* 2$ Research Institute for Production Development \\ (15, Shimogamo Morimoto-cho, Sakyo-ku, Kyoto-shi, T606)
}

\begin{abstract}
Absolute configurations of mytiloxanthin and 9-E-mytiloxanthin isolated from the mussel Mytilus coruscus were confirmed to be $3 R, 3^{\prime} S, 5^{\prime} R$ by using modified Mosher's method.

Key words : Carotenoid, Mytiloxanthin, Absolute configuration, NOE, Mosher's method
\end{abstract}

\section{Introduction}

Mytiloxanthin (1), a red carotenoid which was first isolated from the mussel Mytilus californianus by Sheer ${ }^{1)}$, is wide spread in marine shellfish and sea squirt ${ }^{2), 3)}$. 9-E-Mytiloxanthin (2) is also occurred with 1 as a minor component in these marine animals. In 1973, Khare et $a l .^{4)}$, proposed structure of 1 to be $3,3^{\prime}, 8^{\prime}$-trihydroxy-7,8-didehydro- $\beta, \kappa^{-c a r o t e n}-$ $6^{\prime}$-one by chemical and spectroscopic studies. Subsequently, Chopra et $a l^{5), 6)}$. reported the total synthesis of $9-E-\left(3 R, 3^{\prime} S, 5^{\prime} R\right)$-mytiloxanthin and proposed the same chirality for natural 1 by comparison of stereomutation product of 1 on thin layer chromatography (TLC). However, the absolute configurations of natural 1 and 2 have not beed determined yet since the circular dichroism spectra (CD) of 1 and 2 are extremely weak.

On the other hand, it is well known that the Mosher's method ${ }^{7)}$ and modified Mosher's method $^{8), 9)}$ using $[\alpha$-methoxy- $\alpha$-(trifluoromethyl)phenylacetic acid (MTPA) ester are convenient and important chemical process for determination of the absolute configuration of secondary alcohols and amines. Thus we have applied this method for the determination of the absolute configuration of natural 1 and 2. This paper reports the elucidation of the absolute stereostructures of 1 and 2 isolated from the mussel $M$. coruscus.

\section{Experimental}

\subsection{General experimental procedures}

UV and visible light absorption spectra (UV-VIS) and CD were recorded in ether with a Shimadzu UV-240 and Jasco J-500 C, respectively. ${ }^{1} \mathrm{H}-\mathrm{NMR}$ spectra were measured at 300 $\mathrm{MHz}$ in $\mathrm{CDCl}_{3}$ on a Varian XL-300 with TMS as internal standerd at $22 \sim 24^{\circ} \mathrm{C}$. Mass spectra (MS) were measured with JEOL SX 102A. Preparative TLC was carried out on a plate $(20 \times$ $20 \mathrm{~cm}, 0.5 \mathrm{~mm}$ thick) coated with silca gel 60 (Merck) using hexane/acetone (vol/vol, $7: 3$ ) as solvent. High performance liquid chromatography (HPLC) was performed on a Shimadzu LC-6 AD instrument with a Shimadzu SPD-6 AV spectrophotometer set at $460 \mathrm{~nm}$. The column used was a Shim-pack PREP-ODS with a mobile phase of $\mathrm{CH}_{3} \mathrm{CN} / \mathrm{CH}_{2} \mathrm{Cl}_{2}$ (vol/ vol, $8: 2)$.

Corresponding author : Takashi MAOKA, Research Institute for Production Development 


\subsection{Isolation of mytiloxanthin (1) and $9-\boldsymbol{E}$-mytiloxanthin (2)}

According to the method described previously $\left.{ }^{10}\right), 1(8 \mathrm{mg})$ and $2(2 \mathrm{mg})$ were isolated from $M$. coruscus $(20 \mathrm{~kg}, 30$ specimens) purchased from the fish market in Toba city.

Mytiloxanthin (1) showed UV-VIS : 294 and $469 \mathrm{~nm}$. CD : nm $(\Delta \varepsilon) 225(-0.5), 280(0), 294$ $(+0.7), 305(0)$ and $360(-1.0)$. EI-MS : $m / z$ (relative intensity) $598[\mathrm{M}]^{+}(23 \%), 580[\mathrm{M}-18]^{+}$ (5), $562[\mathrm{M}-36]^{+}(1), 506[\mathrm{M}-92]^{+}(4), 471[\mathrm{M}-127]^{+}(1), 401[\mathrm{M}-197]^{+}(20), 197(17), 179(25)$, 109 (90) and $92(100) .{ }^{1} \mathrm{H}-\mathrm{NMR}$ (Table 1).

9-E-Mytiloxanthin (2): UV-VIS 358 and $465 \mathrm{~nm}$. CD : $\mathrm{nm}(\Delta \varepsilon) 230(-0.8), 247(0), 258$ $(+1.0), 269(0), 295(-1.6), 318(0), 350(+1.1)$ and $368(0) . \mathrm{EI}-\mathrm{MS}: \mathrm{m} / z 598[\mathrm{M}]^{+}(20 \%), 580$ $[\mathrm{M}-18]^{+}(5), 562[\mathrm{M}-36]^{+}(1), 506[\mathrm{M}-92]^{+}(3), 471[\mathrm{M}-127]^{+}(1), 401[\mathrm{M}-197]^{+}(5), 197(6), 179$ (20), 109 (50) and $92(100) .{ }^{1} \mathrm{H}-\mathrm{NMR}$ (Table 1).

Table $1{ }^{1} \mathrm{H}-\mathrm{NMR}(300 \mathrm{MHz})$ Data for Mytiloxanthin (1) and 9-E-Mytiloxanthin (2) in $\mathrm{CDCl}_{3}$.

\begin{tabular}{|c|c|c|}
\hline \multirow[b]{2}{*}{$\mathrm{H}$} & \multicolumn{2}{|c|}{$\delta$ Values in ppm: multiplicity (coupling constants in $\mathrm{Hz}$ ) } \\
\hline & Mytiloxanthin (1) & 9-E-Mytiloxanthin (2) \\
\hline $\mathrm{H}-2 \mathrm{ax}$ & $1.46 \mathrm{~d}, \mathrm{~d}(12,12)$ & $1.49 \mathrm{~d}, \mathrm{~d}(12,12)$ \\
\hline $\mathrm{H}-2$ eq & $1.84 \mathrm{~d}, \mathrm{~d}, \mathrm{~d}(12,3.5,2)$ & $1.86 \mathrm{~d}, \mathrm{~d}, \mathrm{~d}(12,3.5,2)$ \\
\hline $\mathrm{H}-3$ & $3.99 \mathrm{~d}, \mathrm{~d}, \mathrm{~d}, \mathrm{~d}(12,9.5,5.5,3.5)$ & $4.01 \mathrm{~d}, \mathrm{~d}, \mathrm{~d}, \mathrm{~d}(12,9.5,5.5,3.5)$ \\
\hline $\mathrm{H}-4 \mathrm{ax}$ & $2.07 \mathrm{~d}, \mathrm{~d}(17.5,9.5)$ & $2.09 \mathrm{~d}, \mathrm{~d}(17.5,9.5)$ \\
\hline $\mathrm{H}-4$ eq & $2.43 \mathrm{~d}, \mathrm{~d}, \mathrm{~d}(17.5,5.5,2)$ & $2.46 \mathrm{~d}, \mathrm{~d}, \mathrm{~d}(17.5,5.5,2)$ \\
\hline $\mathrm{H}-10$ & $6.46 \mathrm{~d}(11.5)$ & $6.31 \mathrm{~d}(11)$ \\
\hline $\mathrm{H}-11$ & $6.54 \mathrm{~d}(14.5,11.5)$ & $6.87 \mathrm{~d}, \mathrm{~d}(15,11)$ \\
\hline $\mathrm{H}-12$ & $6.36 \mathrm{~d}(14.5)$ & $6.35 \mathrm{~d}(15)$ \\
\hline $\mathrm{H}-14$ & $6.28 \mathrm{~d}(10.5)$ & $6.27 \mathrm{~d}(11)$ \\
\hline $\mathrm{H}-15$ & $6.70 \mathrm{~d}, \mathrm{~d}(14,10.5)$ & $6.70 \mathrm{~d}, \mathrm{~d}(14,11)$ \\
\hline $\mathrm{CH}_{3}-16$ ax & $1.146 \mathrm{~s}$ & $1.191 \mathrm{~s}$ \\
\hline $\mathrm{CH}_{3}-17$ eq & $1.202 \mathrm{~s}$ & $1.257 \mathrm{~s}$ \\
\hline $\mathrm{CH}_{3}-18$ & $1.925 \mathrm{~s}$ & $1.974 \mathrm{~s}$ \\
\hline $\mathrm{CH}_{3}-19$ & $2.014 \mathrm{~s}$ & $2.006 \mathrm{~s}$ \\
\hline $\mathrm{CH}_{3}-20$ & $1.976 \mathrm{~s}$ & $1.950 \mathrm{~s}$ \\
\hline $\mathrm{H}-2^{\prime} \quad \alpha$ & $2.19 \mathrm{~d}, \mathrm{~d}(13.5,8)$ & $2.19 \mathrm{~d}, \mathrm{~d}(13.5,8)$ \\
\hline $\mathrm{H}-2^{\prime} \quad \beta$ & $1.72 \mathrm{~d}, \mathrm{~d}(13.5,4.5)$ & $1.72 \mathrm{~d}, \mathrm{~d}(13.5,4.5)$ \\
\hline $\mathrm{H}-3^{\prime}$ & $4.53 \mathrm{~d}, \mathrm{~d}, \mathrm{~d}, \mathrm{~d}(8.5,8,4.5,2.5)$ & $4.53 \mathrm{~d}, \mathrm{~d}, \mathrm{~d}, \mathrm{~d}(8.5,8,4.5,3)$ \\
\hline $\mathrm{H}-4^{\prime} \quad \alpha$ & $2.88 \mathrm{~d}, \mathrm{~d}(14.5,8.5)$ & $2.88 \mathrm{~d}, \mathrm{~d}(14.5,8.5)$ \\
\hline $\mathrm{H}-4^{\prime} \quad \beta$ & $1.55 \mathrm{~d}, \mathrm{~d}(14.5,2.5)$ & $1.55 \mathrm{~d}, \mathrm{~d}(14.5,3)$ \\
\hline $\mathrm{H}-7^{\prime}$ & $5.861 \mathrm{~s}$ & $5.861 \mathrm{~s}$ \\
\hline $\mathrm{H}-10^{\prime}$ & $7.23 \mathrm{~d}(9.5)$ & $7.23 \mathrm{~d}(10)$ \\
\hline $\mathrm{H}-11^{\prime}$ & $6.62 \mathrm{~d}, \mathrm{~d}(15,9.5)$ & $6.62 \mathrm{~d}, \mathrm{~d}(15,10)$ \\
\hline $\mathrm{H}-12^{\prime}$ & $6.65 \mathrm{~d}(15)$ & $6.65 \mathrm{~d}(15)$ \\
\hline $\mathrm{H}-14^{\prime}$ & $6.38 \mathrm{~d}(10.5)$ & $6.38 \mathrm{~d}(10.5)$ \\
\hline $\mathrm{H}-15^{\prime}$ & $6.65 \mathrm{~d}, \mathrm{~d}(14,10.5)$ & $6.65 \mathrm{~d}, \mathrm{~d}(14,10.5)$ \\
\hline $\mathrm{CH}_{3}-16^{\prime} \quad \alpha$ & $0.851 \mathrm{~s}$ & $0.851 \mathrm{~s}$ \\
\hline $\mathrm{CH}_{3}-17^{\prime} \quad \beta$ & $1.189 \mathrm{~s}$ & $1.189 \mathrm{~s}$ \\
\hline $\mathrm{CH}_{3}-18^{\prime} \quad \beta$ & $1.349 \mathrm{~s}$ & $1.349 \mathrm{~s}$ \\
\hline $\mathrm{CH}_{3}-19^{\prime}$ & $1.976 \mathrm{~s}$ & $1.976 \mathrm{~s}$ \\
\hline $\mathrm{CH}_{3}-20^{\prime}$ & $1.990 \mathrm{~s}$ & $1.990 \mathrm{~s}$ \\
\hline $8^{\prime} 0 \mathrm{H}$ & $16.299 \mathrm{~s}$ & $16.299 \mathrm{~s}$ \\
\hline
\end{tabular}

s, singlet; d, doublet, 


\section{$2 \cdot 3$ Preparation of $(R)$ and $(S)$-MTPA esters of 1 and 2}

Commercially available $(R)$ and $(S)$-MTPA (Aldrich) were used without further purification. To a solution of $1(1 \mathrm{mg})$ in $\mathrm{CH}_{2} \mathrm{Cl}_{2}(5 \mathrm{~mL})$ added $(R)$-MTPA (10mg), 1,3-dicyclohexylcarbodiimide (DCC) $(60 \mathrm{mg})$ and 4-pyrrolidinopyridine $(6 \mathrm{mg})$ and the solution was allowed to stand at room temperature for $12 \mathrm{~h}$ under the darkness. After filtration of reaction mixture, the red solution was subjected to preparative TLC and preparative HPLC affording the $(R)$-MTPA ester of 1 .

$(R)$-MTPA ester of 1 : UV-VIS : 294 and $469 \mathrm{~nm}$. High resolution-FAB MS : $m / z$ 1030.4905 $\left(\mathrm{M}^{+}, \mathrm{C}_{60} \mathrm{H}_{68} \mathrm{O}_{8} \mathrm{~F}_{6}\right.$, calc. 1030.4821).

Another MTPA esters, i.e. $(S)$-MTPA of 1, $(R)$-MTPA of 2 and $(S)$-MTPA of 2 were also prepared by the similar methods described above.

\section{Results and Discussion}

In order to obtain unambiguous total ${ }^{1} \mathrm{H}-\mathrm{NMR}$ assignments and confirm the stereostructures of 1 and $2,{ }^{1} \mathrm{H}^{-1} \mathrm{H}$ nuclear Overhauser effect (NOE) experiments ${ }^{11}$ ) were performed in $\mathrm{CDCl}_{3}$ solution. The results of NOE experiments and complete ${ }^{1} \mathrm{H}-\mathrm{NMR}$ assignments for 1 and 2 are compiled in Fig. 1 and Table 1, respectively. The $3^{\prime}, 5^{\prime}$-trans configuration in $\kappa^{-}$ end group both 1 and 2 was clearly determined by NOE experiments as shown in Fig. 1. Furthermore, NOEs between $\mathrm{H}-19$ and $\mathrm{H}-10$ and between $\mathrm{H}-18$ and $\mathrm{H}-11$ were observed in 2 . These results clearly proved $\triangle 9-E$ geometry in 2 and indicated that $\mathrm{H}-18$ in $\beta$-end group is spatially close to $\mathrm{H}-11$ in polyene as depicted in Fig. 1.

The absolute configurations at $\mathrm{C}^{-} 3$ in $\beta^{-}$end group and $\mathrm{C}^{-} 3^{\prime}$ in $\kappa^{-}$end group in 1 were established by the modified Mosher's method. The $(R)$ and $(S)$-MTPA esters of 1 were prepared by treatment of 1 with the MTPA acids and 1,3-dicyclohexylcarbodiimide (DCC) in $\mathrm{CH}_{2} \mathrm{Cl}_{2}$. The assignments of protones in $(R)$ and $(S)$-MTPA esters of 1 were performed by NOE and ${ }^{1} \mathrm{H}^{-1} \mathrm{H}$ decoupling experiments. The $\Delta \delta(=\delta S-\delta R)$ values ${ }^{9)}$ in the $\beta$-end group and $\kappa^{-}$ end group in MTPA esters of 1 were shown in Fig. 2. The positive $\Delta \delta$ values for the protons oriented on the right side of the MTPA plane ${ }^{9)}$ are the negative $\Delta \delta$ values for the protons located on the left sides of MTPA in the $\beta$-end group disclosed the $R$-configuration at $\mathrm{C}-3$. The $S$ configuration at $\mathrm{C}^{-} 3^{\prime}$ in $\kappa^{-}$end group was also deduced by the $\Delta \delta$ values of the protons as
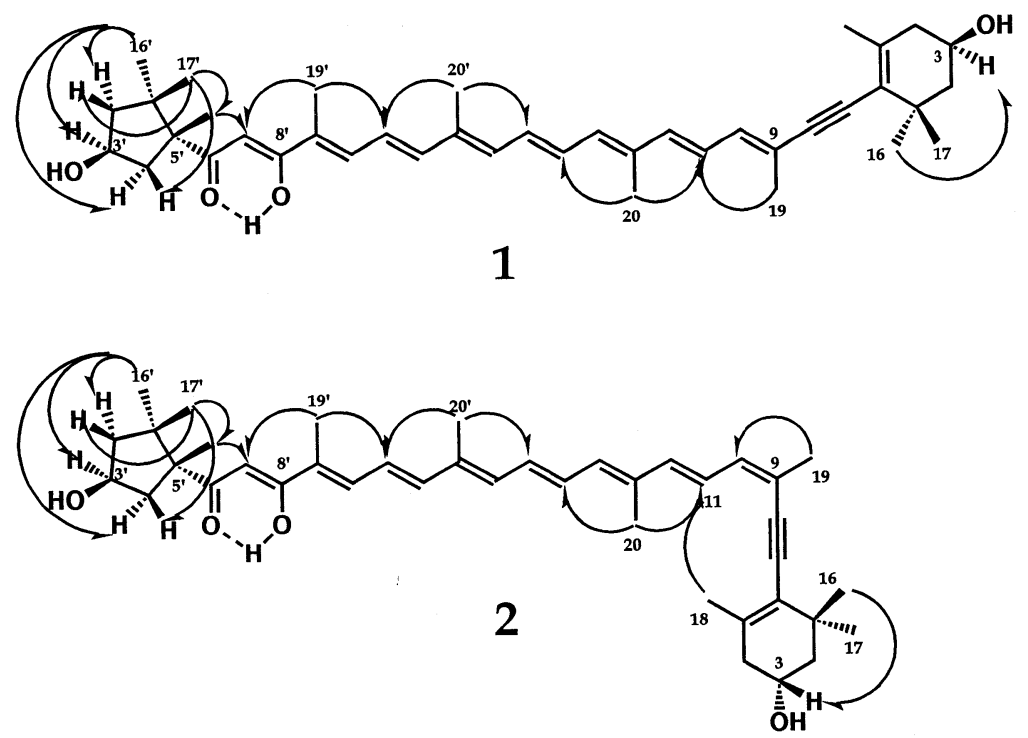

Fig. 1 NOEs of Mytiloxanthin (1) and 9-E-Mytiloxanthin (2). 


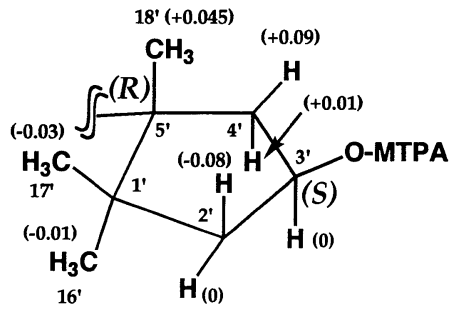

к-end group

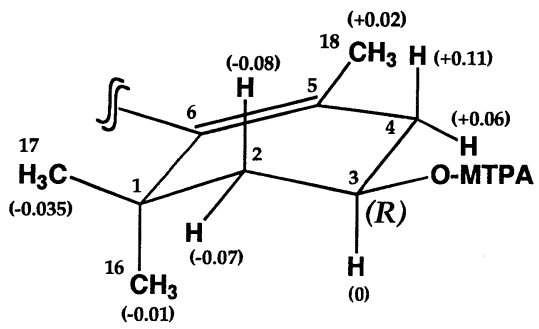

$\beta$-end group

$$
\Delta \delta=\delta(S)-\delta(R)
$$

Fig. $2 \Delta \delta$ Value (ppm) Obtained from MTPA Ester of Mytiloxanthin (1).

shown in Fig. 2. Based on the results of relative stereochemistry in $\kappa^{-}$end group described above, chirality at $\mathrm{C}^{-} 5^{\prime}$ was assigned to be $R$. Consequently, the absolute configuration of 1 has been confirmed to be $3 R, 3^{\prime} S, 5^{\prime} R$. As the similar manner described above, the absolute configuration of 2 was also assigned to be $3 R, 3^{\prime} S, 5^{\prime} R$.

In conclusion, the absolute configuration of natural 1 and 2 were confirmed by NOE experiments and by using of the modified Mosher's method. This method is useful for determination of the absolute configuration of secondary alcohols in carotenoids.

(Received : Feb. 13, 1996 ; Accepted : March 13, 1996)

\section{References}

1) B.T. Sheer, J. Biol. Chem., 136, 275 (1940).

2) T.W. Goodwin, "The Biochemistry of Carotenoids," Vol. II. Animals 2nd ed., Chapman and Hall. London, (1984).

3) T. Matsuno, S. Hirao, Marine Biogenetic Lipids, Fats and Oils., Vol. I. ed. by R.G. Ackmann, CRC Press, Florida, (1989), p. 251.

4) A. Khare, G.P. Moss, B.C.L. Weedon, Tetrahedron Lett., 1973, 3921.

5) A.K. Chopra, G.P. Moss, B.C.L. Weedon, J. Chem. Soc. Chem. Commun., 1977, 467.

6) A.K. Chopra, A. Khare, G.P. Moss, B.C.L. Weedon., J. Chem. Soc. Perkin Trans. I., $1988,1383$.

7) J.A. Dale, H.S. Mosher, J. Am. Chem. Soc., 95, 512 (1973).

8) I. Ohtani, T. Kusumi, M.O. Ishitsuka, H. Kakisawa., Tetrahedron Lett., 30, 3147 (1989).

9) I. Ohtani, T. Kusumi, Y. Kashman, H. Kakisawa, J. Am. Chem. Soc., 113, 4092 (1991).

10) T. Matsuno, T. Maoka, Bull. Japan. Soc. Sci. Fish., 47, 377 (1981).

11) Y. Fujiwara, T. Maoka, M. Ookubo, T. Matsuno, Tetrahedron Lett., 33, 4941 (1992). 


\title{
[ノート Mytiloxanthinおよび9-E-mytiloxanthin の絶対構造
}

\author{
眞 岡 孝 至 $* 1, * 2$ - 藤原 靖 弘 $* 1$ \\ $* 1$ 京都薬科大学 ( 607 京都市山科区御陵中内町5) \\ *2 (財)生産開発科学研究所（疎06 京都市左京区下鴨森本町15）
}

海産二枚貝のイガイ (Mytilus coruscus) から得られたmytiloxanthinおよび 9-E-mytiloxanthinの絶対構造を NOEおよび改良Mosher法を用いるNMR実験によりそれぞれ 3 R，3’S，5’Rと決定した。

（連絡者:這岡孝至）Vo1. 45, No. 7, 667 (1996).

\section{$[ノ ー ト] \quad$ Boreava orienta1isのフェノールイ合物の 酸化防止活性}

眞岡孝至 $* 1$ - 佐久嶋明世 $* 2$ - Maksut Coskun $* 3$ - 伊藤義博 $* 1$

$* 1$ (財)生産開発科学研究所 (i 606 京都市左京区下鴨森本町15)

*2 北海道医療大学薬学部（F061-02 北海道石狩郡当別町金沢1757）

$* 3$ Faculty of Pharmacy, University of Ankara (Ankara, Turkey)

Boreava orientalisの果実より得られた 2 種の新規物質を含む 11 種のフェノール化合物の酸化防止作用を, 2, 2’ーアゾビス (2，4-ジメチルバレロニトリル）（AMVN）によるリノール酸メチルの過酸化系を用いて 検討した。これらの化合物はいずれも酸化防止活性が認められた。シナピン酸（10）およびその誘導体（9）, (11) の活性は，特に顕著であった。 （連絡者:眞岡孝至）Vo1. 45, No. 7, 671（1996）. 